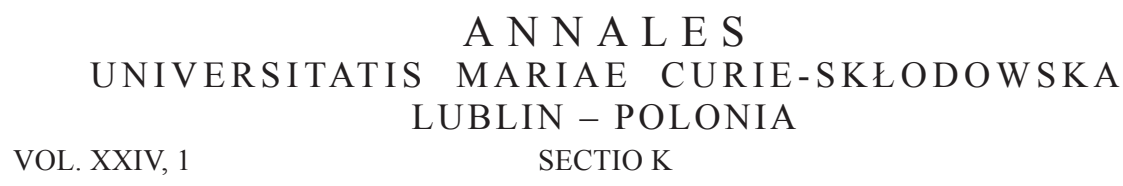

A N N A L E S

UNIVERSITATIS MARIAE CURIE-SKŁODOWSKA LUBLIN - POLONIA

VOL. XXIV, 1

SECTIO K

2017

Department of Sociology, South-West University "Neofit Rilski” in Blagoevgrad, Bulgaria

Faculty of Philosophy, South-West University "Neofit Rilski” in Blagoevgrad, Bulgaria

VALENTINA MILENKOVA, DOBRINKA ST. PEICHEVA

\title{
Middle Class and the Importance of Education. Socio-Cultural and Political Aspects
}

\begin{abstract}
The main idea of the article is to show the importance of education as a factor in identifying the middle class. This means that people with middle class status are involved in various structures of society and they have reached prestigious positions respectively which, in turn, affect the extent of their inclusion in society. Middle-class representatives have complete and successful career realization, and they are significantly more influential from a social point of view in comparison to other individuals which are less integrated and less successful following the public indicators of personal success: education, income, prestige and political power. The paper is primarily based on results obtained through the European Social Survey (ESS) under the 2006, 2009 and 2013 waves. Findings of the present paper are that quality education is not only a function of effort, ambition and persistence, but also of parental involvement, culture capital and family background. Educational achievements are a stimulus for middle-class expansion because they present investment in social contacts and competition on the labour market.
\end{abstract}

Key words: education, higher education, middle class, meritocracy

\section{INTRODUCTION}

The middle class is viewed upon as a current issue which includes both theoretical and practical comprehension of the contemporary social differentiation, in order to create a structural closeness and mobility in society. The middle strata and classes have their own potential for developing society and they reveal their specifics and characteristics in the national context. On the other hand, in a com- 
parative perspective, the middle classes exhibit the presence of convergence in the unfolding of the stratification reality in the separate countries. The grounds for the existence of the middle class, its characteristics and definitions, its structures, forms of developments, semantic connotations, models of consumption - these are the basic themes which have become the subject of research in the academic tradition for the middle class studying. The leading idea is that the middle class is of vast importance in the social plan because it creates stability, ensures a balance and provides growth as it encompasses active, enterprising and educated people. Shortening distances between "top" and "bottom" changed class ratio in economic and power aspects [Treiman, Ganzeboom 2013: 126; Domanski 2006: 87-100; Hanhinen 2001: 13-16]. Middle-class identification under Bulgarian conditions means convergence to the stratification structure in the developed societies and finding similarities with them.

The basic issues of the article are: 1) Prosperity of the society depends on the increased share of the middle class in social context. 2) Education is a specific factor for the creation of the middle class. 3) Education is a prerequisite for individual and social mobility and well-being. Which are the factors often ascribed in modern usage to a "middle class"? The most often forwarded indicators of the middle class are:

- completion of tertiary education,

- holding professional qualifications,

- wealth,

- environment of upbringing,

- social network, manners and values, etc.

This means that people with middle class status are involved in various structures of society and they have reached prestigious positions respectively which, in turn, affect the extent of their inclusion in society. Thus, education and especially higher education is significant prerequisite for the formation of a middle class. Middle class representatives obtain complete and successful career realization, and they are significantly more influential from a social point of view in comparison to other individuals which are less integrated and less successful following the public indicators of personal success: education, income, prestige and power.

\section{EDUCATION AS A CONDITION FOR MIDDLE CLASS}

Education is a basic factor for middle class creation because it is connected with:

- acquiring the "instrumental culture" (Bernstein), including instruction knowledge, skills and qualifications, so education is a prerequisite for higher professionalism and better role conducting;

- passing of "expressive culture" (Bernstein), including rules, norms, values, behavior models, being a condition for more strict following the social rules reflecting the fact that more educated people are more socialized (Inlkeles). 
Education is connected with the transmission of knowledge and norms constructing cultural basis of society. The connection between dominating values and their internalization by individuals are supported through education. Education introduces actors in a world of publicly spread meanings. Education corresponds to individuals' needs for knowledge about man, nature and society, shaping abilities for their orientation in the world, for their comprehension of his/her own place within public structures, for their inclusion in social relations.

Regarding the European Social Survey data [ESS 2006, 2009, 2013], it is noteworthy that in each subsequent year decreased the part of the Bulgarian respondents stating that "people in this country have good opportunities for obtaining education" (Table 1).

Table 1. People has good opportunities for obtaining education (\%)

\begin{tabular}{|l|c|c|c|}
\hline & 2013 & 2009 & 2006 \\
\hline Fully agree & 6.6 & 9.5 & 12.4 \\
\hline Somewhat agree & 26.1 & 27.5 & 26.1 \\
\hline Neither agree, nor disagree & 21.1 & 16.9 & 17.4 \\
\hline Somewhat disagree & 15.5 & 15.7 & 15.7 \\
\hline Fully disagree & 23.5 & 20.4 & 18.7 \\
\hline Don't know & 7.5 & 10.0 & 9.6 \\
\hline
\end{tabular}

Source: Authors' own studies.

In 2013, there is growing percentage of people who do not have a clear position ("neither agree, nor disagree") towards educational opportunities when compared to 2009. The obtained results are indicative that respondents manifested doubts in the national educational system. As a matter of fact, in a normative perspective, several political documents have been adopted concerning increasing educational opportunities for inclusion: National Programme for the development of school education and preschool training and upbringing (2006-2015); Joint Memorandum on Social Inclusion, Bulgaria (2005); Actualized Employment Strategy (2008-2015); Educational Integration of Ethnic Minorities Children and Students Strategy (2005-2015); National Programme for a Fuller Coverage of Students of Obligatory School Age; National Strategy for Lifelong Learning (2014-2020). In reality, however, for a short a period those policy documents did not affect the educational environment.

Education is important in personal and social plan because people with higher education are:

- more critical,

- more open to changes,

- more disposed to improvement,

- better professionals,

- they have ambitious to enhance their qualification, ${ }^{1}$

1 LLL surveys were dedicated to the indicating the attitudes and real activities towards continuation of education and to the increasing of the qualification of higher educated people in the country [Boyadjieva 2012]. 
- they have more knowledge for the world and social situation,

- they find jobs easier and their incomes are higher when compared to incomes of other people,

- they have higher political involvement and responsibility.

The attitude towards criticism and great expectations among people of higher education (who are mainly representatives of the middle class) was demonstrated through the next question: "What is the situation in our educational system?" The estimation [ESS, 2006, 2009, 2013] was made on a 10-grade scale from 00 - "very bad" to 10 - "very good" (Table 2).

Table 2. Situation in the Bulgarian education system (\%)

\begin{tabular}{|r|c|c|c|c|c|c|c|c|c|c|c|c|}
\hline 00 & 01 & 02 & 03 & 04 & 05 & 06 & 07 & 08 & 09 & 10 & Don't know & Year/Round \\
\hline 7.8 & 8.7 & 9.3 & 12.9 & 10.5 & 19.5 & 7.4 & 5.7 & 2.6 & 1.6 & 1.5 & 12.5 & 2009 \\
\hline 12.6 & 10 & 9.2 & 11.5 & 9.3 & 13.4 & 6.5 & 5.9 & 9.1 & 1.2 & 1.4 & 15.9 & 2006 \\
\hline 7.8 & 5.8 & 9.4 & 11.9 & 13.3 & 19.0 & 8.0 & 5.3 & 2.9 & 1.4 & 1.1 & 13.9 & 2013 \\
\hline
\end{tabular}

Source: Authors' own studies.

Education is evaluated as: a process, achievements, institution, rules, norms. One can note from the data that the largest accumulations are in the negative part of the scale. Accumulations in 2009 and 2013 are similar and they are focused on critical considerations which mean that the educational situation in the country has not changed. In addition, $75 \%$ of people giving negative estimation have higher education. That means that higher educated people put forward bigger criteria, greater expectations and demands, due to their continued socialization, training and institutional experience, to their more embracing view on things. Their criticism on the situation in education follows the lack of comprehensive vision for reforms in education, insufficient continuity between different teams at the Ministry of Education, leading to randomness and to piece work. In that sense education faces a number of challenges:

1. A decline in the quality of school education in Bulgaria in the past 20 years. The large-scale Programme for International Student Assessment (PISA 2012), conducted by the OECD, demonstrated that one of the lowest educational attainment results is that of the Bulgarian pupils (especially in mathematics and science). In addition, an external evaluation, conducted within the Bulgarian education system - after $4^{\text {th }}$ and $7^{\text {th }}$ grades - also showed insufficient school attainment results of Bulgarian pupils.

2. A decline in the quality of university education in Bulgaria, especially with the large proliferation of teaching academic institutions.

3. $22 \%$ of the economically active Bulgarian population has only primary or lower than primary level education.

4. In Bulgarian educational institutions, students are being evaluated on the basis of obtained knowledge rather than on the basis of practical competence. The alignment of learning outcomes to labour market needs is tenuous. 
5. Another problem facing education is connected with the increase of violence at schools which is a serious challenge to education. According to Émile Durkheim [1956], education aims at instigating and developing of a certain number of physical, intellectual and moral situations of children, representing society in its entity, as well as the specific social environment. In Durkheim's understanding, discipline has to be recognized as something good and necessary, and in a long-term perspective it creates respect to justice, to impersonal law with its objectivity and comprehensiveness.

In that context, in view of the significance of discipline, one has to interpret the results of the European Social Survey [2009]. The respondent estimate the statement "School has to teach children to order and discipline" and the evaluations of that statement were as follows (Table 3):

Table 3. School has to teach children to order and discipline (\%)

\begin{tabular}{|c|c|c|c|c|c|}
\hline Fully agree & Agree & $\begin{array}{c}\text { Neither agree } \\
\text { nor disagree }\end{array}$ & Disagree & Fully agree & Don't know \\
\hline 71.6 & 24.7 & 1.4 & 1.2 & 0.1 & 1.0 \\
\hline
\end{tabular}

Source: Authors' own studies.

The perception of school as a disciplining institution is an important and stable aspect of social environment, nowadays, however, that becomes very topical because in recent years, school discipline turned into one of the serious deficiencies of Bulgarian education through the increased aggression at schools, violence, alcohol and drug abuse. In fact, deviations cover a very wide range; they include different demonstrations of unacceptable and destructive acts concerning not only children themselves, but the whole school communities and organizational environment. Both parents and teachers, and the whole Bulgarian society share solidarity towards the necessity of stricter rules, establishing order and discipline.

Emphasizing discipline as a serious problem is also connected with dropping out of education (mentioned above), when the more intensively an individual distances him/herself from school, the more he/she becomes isolated and, thus, educational exclusion becomes social as well, meaning non-admission of certain individuals, as bearers of social characteristic features, to the environment, to culture, to contacts in communities, controlling definite resources and acquiring a prestige level, which are attractive and significant. The active participation of the larger part of the population in the general material culture, connected with the organization of production conditions, based on the differentiation of labour and corresponding markets is also significant. The lesser the possibilities of access to material culture, the more societies lose their integrating power. Thus, the precipice between gainers and losers becomes deeper. The imbalance between economic growth and just distribution of wealth gets bigger and the hope that an equality of chances could be attained becomes more uncertain. 


\section{CIVIL AND POLITICAL ACTIVITY}

In addition to that perspective, social viability would depend on degrees of adoption and of inclination to participation in social processes through different types of activities: viewing (listening to) political television (radio) broadcasts, reading newspapers, participation in a political party association, trade union as a part of the creation and attainment of a civil society. Generally, Bulgarian respondents [ESS 2009, 2013] are moderately active: according to the 2009 survey, on a working day, almost half of the respondents sampled (47.1\%) spent between half an hour and an hour and a half watching news and television broadcasts on political and current events. Based on the data obtained, it can be said that in 2013, slightly increased the percentage of people who watch political programs (50.8\%) when compared to 2009 (Table 4).

Overall activities: newspaper reading and listening to radio show small accumulations (Table 4).

Table 4. Time for newspapers, radio and TV news (broadcasts) on a working day (\%)

\begin{tabular}{|l|c|c|c|c|}
\hline & $\begin{array}{c}\text { Watching TV } \\
\text { political broadcasts } \\
(2009)\end{array}$ & $\begin{array}{c}\text { Watching TV } \\
\text { political broadcasts } \\
(2013)\end{array}$ & $\begin{array}{c}\text { Listening to radio } \\
\text { political broadcasts } \\
(2009)\end{array}$ & $\begin{array}{c}\text { Newspaper } \\
\text { reading }^{3} \\
(2009)\end{array}$ \\
\hline No time at all & 10.9 & 6.5 & 11.6 & 12.4 \\
\hline Less than $0.5 \mathrm{hr}$. & 25.5 & 18.5 & 16.1 & 28.8 \\
\hline $0.5-1 \mathrm{hr}$ & 34.4 & 34.8 & 8.8 & 10.7 \\
\hline $1-1.5 \mathrm{hr}$. & 12.7 & 16.0 & 3.7 & 2.2 \\
\hline $1.5-2 \mathrm{hr}$. & 6.6 & 8.4 & 1.8 & 0.7 \\
\hline $2-2.5 \mathrm{hr}$. & 2.4 & 3.8 & 0.6 & 0.1 \\
\hline $2.5-3 \mathrm{hr}$. & 1.1 & 2.2 & 0.6 & 0.1 \\
\hline More than $3 \mathrm{hr}$. & 2.2 & 6.1 & 1.5 & 0.1 \\
\hline Don't know & 4.3 & 3.1 & 55.4 & 45.0 \\
\hline
\end{tabular}

Source: Authors' own studies.

The registered civil and political activity of Bulgarians in 2006, 2009 and 2013 [ESS] is also very low (Tables $5,6,7$ ).

Table 5. Activity in a political party or an action group for the last 12 months (\%)

\begin{tabular}{|l|c|c|}
\hline & 2013 & 2009 \\
\hline Yes & 3 & 3.6 \\
\hline No & 96.7 & 96 \\
\hline Don't know & 0.2 & 0.4 \\
\hline
\end{tabular}

Source: Authors' own studies.

2 This question was not included in the $6^{\text {th }}$ round of ESS -2013.

3 Ibidem. 
Table 6. Trade union membership (\%)

\begin{tabular}{|l|c|c|c|}
\hline & 2013 & 2009 & 2006 \\
\hline Yes, I am a member at present & 5.1 & 4.9 & 5.2 \\
\hline Yes, I have been in the past & 43.2 & 38.8 & 45.6 \\
\hline No & 30.5 & 55.6 & 46.5 \\
\hline
\end{tabular}

Source: Authors' own studies.

Table 7. Political party (association) membership (\%)

\begin{tabular}{|l|c|c|}
\hline & 2009 & 2006 \\
\hline Yes & 5.8 & 6.1 \\
\hline No & 94 & 93.5 \\
\hline Don't know & 0.2 & 0.3 \\
\hline
\end{tabular}

Source: Authors'own studies.

Data quoted here demonstrate that modern Bulgarians - already tired of political events, of promises - are quite disappointed with unrealized expectations of well-being, of justice and of improving of social life. Moreover, a vacuum, which was the result of the clash of hopes (individual and social) and lack of actual practical changes, has appeared. Political activity is dominated by middle class representatives, albeit weakly expressed [ESS 2009]:

- $63 \%$ of respondents included in political parties have a higher education diploma;

- $85 \%$ of persons involved in managerial bodies of political organizations are of higher education;

- $89 \%$ of people watching political TV broadcasts have a university degree;

- $68 \%$ of respondents reading newspapers are of higher education.

In contemporary societies social position has been described and perceived in terms of meritocracy as a function of personal talent and efforts; and those who deserve to succeed - reach it, while the others with lesser possibilities - fail. And because mobility is a movement both "upwards" and "downwards" personal failures are a consequence of the competitive situation and the inability to prove oneself in society. Mobility has different dimensions, but "basic abilities necessary to a consolidation in a social plan include mastering of one basic knowledge and abilities of technological and social nature, which is the possibility for development and actions in a complex and highly technological environment, characterized mostly by the significance of information technologies" [Berghman 1995].

In the long run, processes of social participation are dynamic and multidimensional by nature, they are connected with work and income levels, with degrees of education and abilities, with citizenship, and participation in local community. In order to achieve success, members of a community or society have to share different institutions - school, health care, public transport. Those shared institutions contribute

\footnotetext{
4 Ibidem.
} 
to the feeling of solidarity in the population, which is why exclusion and inclusion can be considered in "economic, political, social terms" [Giddens 2001: 323].

In that context we can identify the role of education as a factor for mobility and prosperity, as a condition for advancement and stability, because, in fact, it is not coincidence that it is education and science that are evaluated as "driving forces" of European society, referred to as "knowledge society" and "whole life studying society".

\section{EDUCATION AND THE MIDDLE CLASS EXPANSION}

The actual occupation of the "middle" position is a result of the development of the overall contemporary social structure, the socio-group nature, and specific, socio-economic power, cultural, and consumption patterns, basically, the overall stratification status determines the strata of the entrepreneurs, intellectuals and administrators to be in the middle groups. In the specific case, the sustainability of the middle class definition is in the preserving and reproduction of the hierarchy as a basic principle in the organizational and social structure as a whole, the preserving of the basic hierarchies in societies.

Education plays a key role in increasing chances; it is a necessary and important condition for taking a professional position and middle class statutes, as education is a form of investment in better qualification and level of knowledge. The role of education as a mobility stimulus reveals itself most clearly when it is observed for a longer period of time on the basis of a cohort analysis, allowing for observing the transitions in the framework of the cohort itself (inter-generation perspective) and in relation to parents, i.e. in inter-generation section. The effect of educational expansion depends on the initial position and class affiliation of individuals, as well as on preferences and the level of "saturation" of the very educational institutes. In that sense, one can state that the dimensions of individual and social mobility are not identical. There are surveys [Shavit, Blossfeld 1993], according to which, the effect of the social origin is strong at the beginning of the educational career and then it decreases with later degrees of training; there are two possible explanations for the decreasing of the effects of the origin on successful transitions:

- an explanation, depending on arguments following the differences in family life; here the effects decrease through transitions, but they remain constant within cohorts;

- an explanation, connected with a selection process; here social groups become more similar in relation to some variables - abilities, ambitions, motives [Mare 1981], leading to a stronger effect of the observed socio-economic factors [Shavit, Blossfeld 1993: 2-20].

However, the educational expansion process in all industrialized countries marks a decrease of inequalities in educational opportunities between socio-economic strata [Shavit, Blossfeld 1993: 15], in spite of the existence of surveys showing that the 
inequality in educational opportunities is almost stable over time [Shavit, Blossfeld 1993: 2]. That is why it can be maintained that the role of education as a factor of class support is compatible with: the increased entering of children from the working class into higher educational levels and with ascending educational and class mobility [Goldthorpe 2007: 96]. Education as a mobility factor in Bulgarian society was presented in other surveys [Mihailov 1988] $]^{5}$.

The theoretical works are based on the optimistic view on the potential role of education to improve life chances of individuals from different social strata. However, the formulation of such conceptions cannot be separated from the dominating political ideas of the second half of the $20^{\text {th }}$ century. In most Western European societies, beliefs in individuals' rights connected with the "new" place of man in social life are widespread. The ideas of freedom and rights unambiguously define the theses for equality in the access to: goods, educational achievements, and well-being. In relation to education, concepts proclaiming it as a condition for the so-called contest mobility [Turner 1971: 171-189], presuming to guarantee to individuals a possibility for a sufficiently long training which is not predetermined by social origin, and selection to be realized at a relatively later stage, are becoming popular. Education obtains a predominant role for an individual's success and his/her social position. Birth status ceases to be of leading importance in relation to the future and is transformed into merit status, including education level as one of the important indicators (even the most important one). According to Bulgarian respondents [ESS 2006], education is important for success in today's life (Table 8).

Table 8 . The extent to which education is important for success in today's life $(\%)^{6}$

\begin{tabular}{|c|c|c|c|c|c|}
\hline $\begin{array}{c}\text { Exceptionally } \\
\text { important }\end{array}$ & Very important & Important & $\begin{array}{c}\text { Not quite } \\
\text { important }\end{array}$ & $\begin{array}{c}\text { Absolutely not } \\
\text { important }\end{array}$ & Don't know \\
\hline 42.4 & 30.4 & 17.7 & 5.1 & 1.6 & 2.8 \\
\hline
\end{tabular}

Source: Authors' own studies.

It can be noted that $90.5 \%$ of the respondents have pointed to education as an important condition ("exceptionally important", "very important", and "important") for prosperity. In addition, the fact that education is evaluated as a significant existential circumstance can be noticed in the educational profile of respondents and their environment (Table 9).

\footnotetext{
5 Data from the survey established that in comparison with the year 1966, social groups went through dynamical increasing of their education and status [Tilkidjiev 1988: 284-286].

6 This question was not included in ESS from 2009 and 2013.
} 
Table 9. Educational profile of respondents (\%)

\begin{tabular}{|l|c|c|c|}
\hline \multicolumn{1}{|c|}{2013} & Respondent & Father & Mother \\
\hline Lower than elementary & 2.1 & 9.2 & 12.8 \\
\hline Elementary & 3.7 & 10.4 & 11.9 \\
\hline Basic & 22.3 & 37.1 & 35.3 \\
\hline Secondary & 48.7 & 28.8 & 27.7 \\
\hline College & 4.1 & 1.7 & 3.3 \\
\hline Higher & 18.7 & 8.1 & 6.7 \\
\hline $\begin{array}{l}\text { Postgraduate qualification/aca- } \\
\text { demic degree }\end{array}$ & 0.4 & 0.1 & 0.1 \\
\hline
\end{tabular}

\begin{tabular}{|l|c|c|c|}
\hline \multicolumn{1}{|c|}{2009} & Respondent & Father & Mother \\
\hline Lower than elementary & 2.4 & 6.2 & 8.2 \\
\hline Elementary & 5.1 & 12.3 & 32.7 \\
\hline Basic & 22.1 & 33.1 & 32.1 \\
\hline Secondary & 49.4 & 34.1 & 3.8 \\
\hline College & 4.6 & 1.9 & 6.6 \\
\hline Higher & 15.2 & 8.5 & 0.2 \\
\hline $\begin{array}{l}\text { Postgraduate qualification/aca- } \\
\text { demic degree }\end{array}$ & 1.1 & 0.1 & 0.3 \\
\hline
\end{tabular}

\begin{tabular}{|l|c|c|c|}
\hline \multicolumn{1}{|c|}{2006} & Respondent & Father & Mother \\
\hline Lower than elementary & 2.4 & 7.6 & 9.8 \\
\hline Elementary & 6.4 & 13.1 & 15.0 \\
\hline Basic & 24.3 & 35.5 & 34.9 \\
\hline Secondary & 45.6 & 26.9 & 25.1 \\
\hline College & 6.1 & 2.0 & 4.4 \\
\hline Higher & 15.1 & 7.9 & 5.3 \\
\hline Don't know & 0.2 & 6.9 & 5.6 \\
\hline
\end{tabular}

Source: Authors' own studies.

Compared data concerning the educational profile of respondents and their parents show a change in direction of increase of educational status, which is indicative for: 1) the presence of inter-generation mobility; 2) the fact that education is considered and estimated as an important factor for success and individual development; 3 ) the fact that the number of both secondary and higher education respondents and their parents has increased in 2009 when compared to 2006; 4) increasing the share of respondents with higher education in 2013 when compared to 2009. All that comes to support the thesis that education is not only a value, it is actually mapped on educational strategies of Bulgarians (although, as a matter of fact, educational aspirations and realized strategies of Bulgarians are marked with certain modesty, related to a European scale).

At the same time, educational achievements are not only a function of efforts and ambitions but also of family involvement which means that education attainments and well-being are connected with family environment and its importance for individuals. That is so because high parental status creates conditions for children to attain - just like their parents - high educational achievements and positions. 


\section{EDUCATIONAL ACHIEVEMENTS AND FAMILY}

The role of family and the influence of educational status of middle class parents on generations are expressed through the choice of a school by children. The school choice is actually ruled by specific determinants of parents' social and educational identity, but it is also dependent on economic and financial living conditions. In that sense, even when there is no expressed partiality when it comes to selection of students, its social character is preserved due to social definiteness of educational attainments [Grusky 2008; DiMaggio 1982].

We have studied the parents' educational status of students in several Bulgarian foreign languages high schools, supporting the thesis of cultural capital and reproduction [Bourdieu 1977; Bourdieu, Passeron 1977]. Cultural capital as a system of implicit and deeply internalized values and resources transferred to generations is influenced by social class, race (ethnos) and parents' education [Lareau, Weininger 2003]. Cultural capital examined as particular cultural practices, activities, resources, concerns school results, educational attainments and future social individual choices [Ganzeboom et al. 1990; Kalmijn, Kraaykamp 1996; Dumais 2002].

Educational values, embodied into mechanisms of educational system urge parents and students to compete for places at high quality schools - they choose to take part in that competition and so they become part of the reproduction of the dominant culture when they value one type of education and not another; when they tolerate particular skills and qualification, which actually are artefacts. Following of the dominant culture by families symbolizes gaining mobility resources through access to high status education. And so it turns out that school choice is one of the significant biographical acts, and, as Anthony Giddens stated, the choice connects "power" and "stratification" [Giddens 1995]. It is important to put an accent on diverse institutional nets in which children contact as well as on to the parents' effort to guide their children's success in specific fields.

Through the following analysis we are going to try and show how cultural capital inherited through family and incorporated into children is transferred to respective educational institutions, which tolerate a particular type of profiling and socialization, which ultimately leads to the reproduction of the capital. Important indicator for the definition of school prestige can be derived by the number of the candidates for this institution. In the last five years (2008-2013), 71\% of the candidates (after the $7^{\text {th }}$ grade) in the City of Sofia have indicated, among their first five preferences, several foreign language schools - the German Language High School, the First English Language High School, the Spanish Language High School, the Second English Language High School, and the French Language High School. Subsequently, the entrance grades for those schools were the highest - in that order ${ }^{7}$. Thus, selective schools.

${ }^{7}$ For that reason, in the following analysis, the notion of "elite schools" implies foreign language 
process becomes possible just because of the great number of candidates and one can select the best among them, in that case, the individuals with the highest grades.

Language high schools show the following important features, which distinguish them substantially from the other secondary educational institutes:

1. High degree of selectivity at the entrance in the choice of pupils;

2. A specific individual profile of teachers, combining high professionalism with higher expectations and demands by their students.

3. Competitive spirit and great competitive power of graduates of foreign language schools in continuing their education at higher schools. Middle class parents know that education in middle school, which ensures the enrollment in a good university, is especially important for the future life chances of their children [Roberts 2015: 93-108].

\section{EMPIRICAL DATA}

As a result of the 2010 non-representative survey of 360 students chosen randomly from German, English, Spanish and French language high schools in Sofia (90 persons from each school) it was established that for $61.1 \%$ of persons (220), their parents were also graduates of a foreign language $\mathrm{school}^{8}$. In addition to those data, there are presented some results from a survey (following "experimental design" schedule) and carried out in 1996 at three foreign language schools: English, French and German schools and at two comprehensive schools - No. 81 and No. 40 (comprising the control-group) - in Sofia'. The subject of analysis was the surroundings - family and school, as well as its features: education and profession of parents, specific characteristics of educational process and environment, teachers and children achievements.

\section{EDUCATION OF RESPONDENTS' PARENTS}

- fathers: $92.0 \%$ from the English language school had a university degree, 95.6\% from the German language school and $93.2 \%$ from the French language school, while $46.7 \%$ from school No. 81 and $42.2 \%$ from school No. 40 had a higher education diploma;

- mothers: with higher education - 85.6\% from the English language school, 91.9\% from the German language school, 92.2\% from the French language school as opposed to $45 \%$ from School No. 81 and $42.0 \%$ from School No. 40 .

8 Using a standardised interview with respondents as the main research technique is focussed on the education and profession of parents in more detail later on.

9 Control-group was important for results. There were 100 students and 10 teachers from each school to be surveyed. The methodology included standardised interview with teachers, group inquiry with students, information of the state of the school given by schoolmasters, opinions of experts from the Regional Inspectorate in Sofia on 10 school subjects. 
It is necessary to note the tendency that husbands in the middle-class family have a similar educational background, which creates a trans-generational reproduction, distinct middle-class lifestyles, and compete for higher positions than their parents [Roberts, 2015: 93-108].

\section{PROFESSION}

The parents of the respondents from foreign language schools were mainly middle-class statuses (over $85 \%$ ) - doctors $(25 \%)$, teachers $(4 \%)$, engineers $(7 \%)$, diplomats (3\%), lawyers (21\%), economists ( $9 \%)$, scientists (5\%), journalists $(11 \%)$, $12 \%$ ran their own business; compared to less than $30 \%$ of the representatives of the middle class from the control-group of schools Nos. 81 and 40 (Sofia).

It is clear from those data that individuals coming from the middle class were not only potential candidates, but the most frequent users of foreign language training as well. And that is so, because middle-class representatives in any case guarantee a greater affinity to those linguistic and social practices supporting them, while generational traditions and life styles affordable to those families gave a significant advantage to their representatives. Foreign language secondary schools, to a greater extent than general education schools, are identified as places for confirming meritocracy standards, supported by teachers' demands as well. In general, on the background of the decreasing quality of education, and that was shared by all the Inspectorate experts, as well as by the interviewed teachers, foreign language schools were to a lesser extent influenced by devaluation of educational grades and marks.

In the process of thinking, one somehow gets lost in what is prerequisite and what is a consequence, what is cause and what is the result, as talented students demand highly qualified teachers, and the latter stimulate the intellectual development of their students, their aspirations and ambitions. But that is only on the first glance because within the framework of an elite school predominant place and sensible role is given to selection, starting at the "entrance", passing through the training process and at the "exit". Language schools can support a definite element of continuity between parents and children in this country, as well. It is necessary to emphasize the fact that $61 \%$ of students from the non-representative sample had parents who graduated a foreign language school. That fact in itself is indicative of raising language school position as a recognized institutional mechanism of socialization being closest to family expectations and aspirations [Bourdieu 1989]. In that aspect, we have followed up cultural capital including educational and professional profile of parents, cultural practices, and tastes, valid both for families and for children. 


\section{CONCLUSIONS}

In conclusion, the following basic issues, connected with the significance of education to the middle class, can be presented:

1. Key factor for the establishment of the middle class is education (higher education). Representatives of the middle class are more demanding in terms of active school involvement in pupils' actions and life.

2. Education becomes important for middle-class families, not only according to how and where their children study, but also due to the higher transparency and the connection between the educational routes and employment in the middle class [Roberts 2015].

3. There are good conditions for education in the country although educational system is not highly valued by the people and they are of critical opinion on education and education process.

4. There is a real process of increasing of educational level (secondary and higher education) in the country. That is an indicator of intergenerational mobility.

5. Education is an important factor for success in society: high social statuses and political culture of people confirm that.

6. Personal ambitious for education are important but necessary are also: investments, successful economy, employment market, sustainable political system.

7. Family and its resources have relation to educational achievements of pupils.

8. According to respondents, education is "important for the success in life today".

9. Educational achievements are a stimulus for the middle class expansion because they are the basis for investment in social contacts and competition in the labour market.

10. Social viability depends on degrees of adoption and of inclination to participation in social processes through different types of activities: watching (listening to) political television (radio) broadcasts, reading newspapers, participation in a political party association, trade union as a part of a creation and attainment of a civil society.

Along with all that was said, one has to underline the great significance of the presence of individual educational aspirations, but an environment where those ambitions can be realized and which supports the realization of one's intentions is also necessary. This means that personal aspiration towards education is not a sufficient condition for individual and social mobility. So as to provide people with the opportunities that would help them to achieve success in life, investments in the field education have to be made. There is a need for training conditions to be supplied by a successful economics, stable bank system, opened workplaces, or sustainable political system. Only then will the middle-class representatives gain personal satisfaction. 


\section{BIBLIOGRAPHY}

Berghman, J. 1995. Social Exclusion in Europe: Policy Content and Analytical Framework, [in:] Beyond the Threshold: The Measurement and Analysis of Social Exclusion, G. Room (ed.), Policy Press, Bristol. Bourdieu, P. 1989. La Noblesse d'etat, Editions de Minuit, Paris.

Bourdieu, P., Passeron, J.-C. 1977. Reproduction in Education, Society and Culture, Sage, Beverly Hills. Bourdieu, P. 1977. Cultural Reproduction and Social Reproduction, [in:] Power and Ideology in Education. J. Karabel, A.H. Halsey (eds.), Oxford University Press, New York.

Boyadjieva, P. (ed.) 2012. The Lifelong Learning Hybrid. Policy, Institutions and Learners in Lifelong Learning in Bulgaria, Iztok-Zapad, Sofia.

DiMaggio, P. 1982. Cultural Capital and School Success: The Impact of Status Culture Participation on the Grades of U.S. High School Students, “American Sociological Review”, vol. 47, pp. 189-201.

Domanski, H. 2006. The Middle Class in Transition from Communist to Capitalist Society, [in:] Building Democracy and Civil Society East of the Elbe, S. Eliaeson (ed.), Routledge, London.

Dumais, S.A. 2002. Cultural Capital, Gender, and School Success: The Role of Habitus, "Sociology of Education", vol. 75, pp. 44-68.

Durkheim, E. 1956. Education and Sociology, Free Press, New York.

European Social Survey, 2006, 2009, 2013.

Ganzeboom, H.B.G., De Graaf, P.M., Robert, P. 1990. Cultural Reproduction Theory on Socialist Ground: Intergenerational Transmission of Inequalities in Hungary, [in:] Research in Social Stratification and Mobility, A.L. Kalleberg (ed.), JAI Press, Greenwich (CT).

Giddens, A. 1995. Politics, Society, and Social Theory: Encounters with Classical and Contemporary Social Thought, Polity Press, Cambridge.

Giddens, A. 2001. Sociology, $4^{\text {th }}$ ed., Polity Press, Cambridge.

Goldthorpe, J.H. 2007. Cultural Capital: Some Critical Observations, [in:] From Origin to Destination: Trends and Mechanisms in Social Stratification Research, S. Scherer, R. Pollak, G. Otte, M. Gangl (eds.), University of Chicago Press, Chicago.

Grusky, D.B. (ed.) 2008. Social Stratification: Class, Race, and Gender in Sociological Perspective, $3^{\text {rd }}$ ed., Westview Press, Boulder.

Hanhinen, S. 2001. Social Problems in Transition, Kikimora Publications, Helsinki.

Kalmijn, M., Kraaykamp, G. 1996. Race, Cultural Capital, and Schooling: An Analysis of Trends in the United States, "Sociology of Education", vol. 69, pp. 22-34.

Lareau, A., Weininger, E.B. 2003. Cultural Capital in Educational Research: A Critical Assessment, "Theory and Society", vol. 32, pp. 567-606.

Mare, R. 1981. Change and Stability in Educational Stratification, "American Sociological Review", vol. 46, pp. 72-86.

Mihailov, S. (ed.) 1988. Empirical Sociological Survey "The Town and the Village '86”, vol. 3, Sofia.

Roberts, K. 2015. Class Formation and Distinction: Twenty-Five Years of Change in Eastern Europe, [in:] Middle Class as a Precondition of a Sustainable Society: Fifteen Years Later, M. Kelyan (ed.), Avangard Prima, Sofia.

Shavit, Y., Blossfeld, H.P. (eds.) 1993. Persistent Inequality: Changing Educational Attainment in Thirteen Countries, Westview Press, Boulder.

Tilkidjiev, N. (ed.) 1988. Social Stratification and Inequality, M8M, Sofia.

Treiman, D.J., Ganzeboom, H.B.G. 2013. Educational Achievement in Comparative Perspective, Population Working Paper, UCLA, California Center for Population Research, Los Angeles.

Turner, R.H. 1971. Sponsored and Contest Mobility and the Social System, [in:] Readings in the Theory of Educational Systems, E. Hopper (ed.), Hutchinson, London. 


\section{BIOGRAPHIES}

Valentina Milenkova, professor, head of the Department of Sociology at the SouthWest University "Neofit Rilski", in Blagoevgrad (Bulgaria) (https://ais.swu.bg/ profile/vmilenkova). She holds lectures on "Sociology of Education" and "Social Stratification and Inequalities". She defended her doctoral thesis on "Education and Social Reproduction" at the Institute of Sociology of the Bulgarian Academy of Sciences. On this basis, Milenkova has also provided scientific consultancy to the Bulgarian Ministry of Education and Science, NESET and the Open Society Foundations. Milenkova has worked on the broad area of social dimension of education and training policies as a researcher and lecturer. She has 10 monographs and about 90 articles in Bulgarian and foreign journals. Milenkova is a member of the Editorial boards of the "Romanian Journal of Social Sciences" and "Education Research Journal". Her research interests are particularly focused on educational policies for ethnic minorities, social inequalities, and the significance of education. E-mail:vmilenkova@gmail.com

Dobrinka St. Peicheva, full professor, head of Laboratory of Sociology at the South-West University "Neofit Rilski" in Blagoevgrad (Bulgaria) and head of the International Seminar Media and Education. Member of MC of two COST Action in the field of media and politics; head of 5 national academic projects; national coordinator of two international projects; participant in 2 international projects. Regular Member of IAMCR (International Association for Media and Communication Research) since 2007. Member of ICA (International Communication Association) in the years 2007-2010. Main books: Digitalization and Social Transformations (ed.), Blagoevgrad 2017; Sociological Spaces (ed.), Blagoevgrad 2015; Mass Media Effects, Blagoevgrad 2014; Mass Media Effects, Blagoevgrad 2012; Mediatized Reality, Blagoevgrad 2012; Economics and Communication. The World of Communication and Media Society, Sofia 2003. Authoress of more than 50 other publications in Bulgaria and abroad. E-mail: peichevadobrinka@abv.bg 